\title{
PEMBERDAYAAN DAN PENDAMPINGAN PENGEMBANGAN DESA WISATA SUKARATU KABUPATEN SERANG BERBASIS PUBLIC PRIVATE PARTNERSHIP
}

\author{
Budi Hasanah $^{1}$, Annisarizki², Sigit Surahman ${ }^{3}$ \\ ${ }^{1}$ Prodi Ilmu Administrasi Publik Universitas Serang Raya \\ ${ }^{2}$ Prodi Ilmu Komunikasi Universitas Serang Raya \\ ${ }^{3}$ Prodi Ilmu Komunikasi Universitas Serang Raya \\ budihasanah@gmail.com, annisarizzkii@gmail.com, \\ saleseven@gmail.com
}

\begin{abstract}
Abstrak
Secara legal Desa Sukaratu telah menjadi desa wisata sejak tahun 2018. Destinasi pertama yaitu "Mahkota Ratu", dan pada pertengahan tahun 2019, telah dibuka destinasi wisata baru bernama "Taman Pesona". Desa wisata ini bisa terus dikembangkan sehingga dapat menjadi desa wisata yang dapat diperhitungkan baik di tingkat lokal maupun nasional. Namun dalam pengembangannya, butuh adanya kerjasama dengan berbagai pihak berbasis public private partnership agar dapat mengeksplor potensi yang ada dengan baik. Tujuan pengabdian ini memberikan materi dan pendampingan pada aspek community involvement melalui kegiatan pemberdayaan dan pendampingan berbasis public private partnership. Metode kegiatan dengan menggunakan particiaptory learning and action. Kesimpulan dari kegiatan ini, peserta dapat mengikuti kegiatan dengan baik. Tingkat keberhasilan diukur dengan skala empat (excellent, verry good, Acceptable, dan not Acceptable). Indikator keberhasilan dengan tingkat keberhasilan $75 \%$ dan $73 \%$ pada kegiatan penyuluhan pertama dan kedua serta $70 \%$ pada kegiatan pelatihan yang masuk pada skala sangat baik meskipun masih perlu dilakukan pendampingan oleh fasilitator. Rekomendasi dalam kegiatan ini adalah perlu ditambahkan mitra baik dari pihak pemerintah atau swasta dan terjalin kerjasama yang kuat dalam mengembangan desa wisata sukaratu sehingga outcome yang diterima kembali lagi untuk kesejahteraan masyarakat khususnya masyarakat lokal Desa Sukaratu.

Kata kunci : Pemberdayaan, pendampingan, pengembangan, desa wisata, public private partnership, community involvement, Desa Sukaratu
\end{abstract}

\section{PENDAHULUAN}

Otonomi daerah telah menghasilkan berbagai upaya optimaliasi pemberian pelayanan bagi masyarakat sampai pada tingkat lokal dalam hal ini adalah desa. Pelayanan memperluas atas terimplementasinya asas keadilan sosial yang diberikan kepada masyarakat sesuai dengan amanat konstitusi. Tidak hanya keadilan sosial "sekali jalan" tetapi perlu adanya konsep sustainable development. Hal ini seiring dengan agenda pembangunan berkelanjutan (MDGs) yang dicanangkan oleh negara-negara anggota PBB yang dilaksanakan sampai tahun 2030. Pembangunan

$$
\text { Lingkungan Hidup dan Bencana }
$$


yang berhasil selain dari faktor keadilan sosial yang erat hubungannya adalah faktor lingkungan. Dengan demikian, seperti masalah kerusakan alam yang dapat mengganggu kesinambungan pembangunan, faktor keadilan sosial juga merupakan semacam kerusakan sosial yang bisa mengakibatkan dampak yang sama. Unsur-unsur pembanguan tersebut dapat dilihat pada gambar 1 .

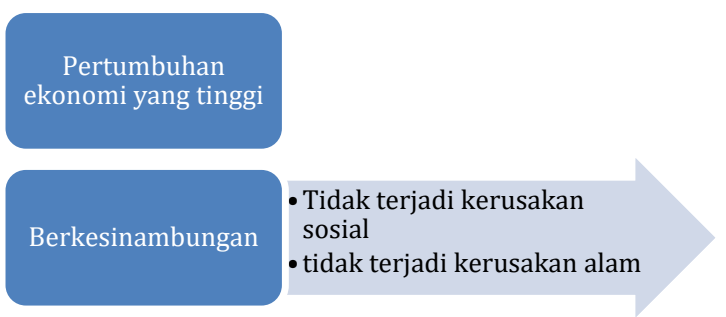

Gambar 1: Unsur-unsur pembagunan yang berhasil Sumber : Budiman, 1996:8

Otonomi tingkat desa memiliki ruang yang cukup besar dalam mengekspresikan kreatifitas dan inovasi demi terwujudnya kemajuan desa itu sendiri. Dalam hal ini setiap desa memiliki keunikannya masing-masing seperti pada aspek budaya, bahasa, alam, masyarakat, ekonomi, teknologi, adat, suku yang dapat dieksplor dengan baik sehingga dapat dimanfaatkan dengan produktif. Salah satu desa yang dimaksud adalah Desa Sukaratu Kecamatan Cikeusal Kabupaten Serang Provinsi Banten. Desa ini memiliki modal sosial yang cukup baik, sumber alam seperti terbentangnya perkebunan bambu, rambutan, durian dan persawahan tanaman padi. Selain itu, desa ini juga secara legal sudah menjadi desa wisata pada tahun 2018. Desa wisata yang saat ini memiliki dua destinasi yaitu taman mahkota ratu yang telah di resmikan kurang lebih setahun yang lalu dan taman pesona yang baru ini tahun 2019 di resmikan. Namun terdapat beberapa permasahan yang ada di Desa ini. pertama, tidak sedikit warga Desa Sukaratu paham mengenai desa wisata atau dengan kata lain tidak sadar wisata. Padahal partisipasi masyarakat setempat dibutuhkan dalam pengembangan desa wisata. Seperti penyediaan layanan minimal berbasis masyarakat yaitu ketersediaan akomodasi/homestay, penyewaan transportasi lokal. Kedua, infrastruktur yang kurang baik. Terlihat jalan sempit menuju Desa Wisata Sukaratu hanya mampu dilalui oleh satu mobil (satu arah) namun realita pemanfaatan jalan ini dilalui dua arah serta jalan yang gelap, terjal sehingga sangat berbahaya bagi keselamatan. Ketiga, belum ada produk kreatifitas kerajinan lokal, salah satunya bisa dijadikan souvenir. Padahal jika dilihat, Desa Sukartu memiliki potensi hasil alam yang memadai seperti perkebunan bambu, rambutan, durian. Hasil perkebunan ini belum dieksplor dengan baik. Hasil panen buah rambutan dan durian dijual dalam bentuk buah yang menghasilkan pendapatan jauh lebih kecil dibanding jika buah tersebut diolah kembali seperti dibuat menjadi cemilan dodol, keripik rambutan, asinan rambutan, manisan rambutan dan hasil kreativitas lainnya sehingga secara sosial dan perekonomian, masyarakat lebih berdaya, mandiri, berpenghasilan baik dan dapat membuka lapangan pekerjaan di tingkat lokal. Jika diolah kembali menjadi makanan lain yang lebih menarik selain masyarakat belajar memanage perkebunan sehingga tidak kehabisan stock buah jika tidak musim. Selain itu, terdapat potensi bambu yang melimpah yang sampai saat ini belum dimanfaatkan dengan optimal. Sampai saat ini banyak dari masyarakat yang menjual dalam bentuk bambu yang hanya dihargai seribu rupiah per bambu sedangkan jika dibuat menjadi kerajinan lain dengan berbahan dasar bambu memiliki daya jual yang lebih tinggi. Oleh karena itu perlu adanya pemberdayaan dan pendampingan pengembangan di desa ini.

Pemberdayaan masyarakat menurut Budimanta yaitu kegiatan pengembangan masyarakat yang diselenggarakan secara sistematis, terencana, dan diarahkan untuk memperbesar akses masyarakat guna mencapai kondisi sosial, ekonomi, dan kualitas kehidupan yang lebih baik (Triyono, 2014:114). Lebih khusus, arah pemberdayaan masyarakat desa di Desa Sukaratu dalam mewujudkan masyarakat desa yang mandiri dapat dilihat dari tiga sisi. Pertama, penciptaan iklim yang memungkinkan potensi masyarakat berkembang (enabling). Artinya, tidak ada masyarakat yang sama sekali tanpa daya. Oleh karena itu perlu dbangun daya tersebut dengan cara mendorong, memotivasikan, dan membangkitkan kesadaran terhadap potensi yang dimilikinyaserta berupaya untuk mengembangkannya. Kedua, upaya memperkuat potensi yang dimiliki oleh masyarakat (empowering) dengan langkah-langkah yang lebih positif meliputi langkah-langkah nyata dan menyangkut penyediaan berbagai masukan (input)

$$
\text { Lingkungan Hidup dan Bencana }
$$


serta pembukaan akses dalam berbagai peluang yang membuat masyarakat jadi berdaya. Ketiga, perlindungan dalam proses pemberdayaan tanpa menjadi bergantung pada berbagai program pemberian, melindungi dari segala upaya persaingan yang tidak seimbang dan eksploitasi yang kuat atas yang lemah. Namun, tujuan akhir dari proses ini adalah memandirikan masyarakat, memampukan dan membangun kemampuan untuk kemajukan masyarakat ke arah kehidupan yang lebih baik secara berkesinambungan (Rosidin, 2019: $75)$.

Proses kegiatan pemberdayaan didalamnya terdapat kegiatan pendampingan. Pendampingan desa tidak hanya sekedar menjalankan amanat UU Desa tetapi juga modal penting untuk mengawal perubahan desa dalam mewujudkan desa mandiri yang dilakukan secara utuh (Susanti, 2017:29) Berbagai permasalahan tersebut perlu adanya intervensi dari berbagai pihak untuk membantu agar desa wisata tersebut dapat bertahan dan dapat menjadikan Desa Wisata Sukaratu menjadi desa wisata yang berkembang atau bahkan maju dan mandiri. Intervensi disini perlu adanya mitra atau kerjasama atau berkolaborasi dengan pihak lain. Salah satu di dalam tujuan MDGs adalah partnership fot the goals antarpihak agar tujuan pembangunan yang berkelanjutan dapat tercapai. Pembagunan tingkat lokal, dalam hal ini desa sangat penting dilakukan tidak hanya dilakukan oleh pemerintah tetapi perlu adanya kerjasama atau bermitra atau berkolaborasi antarpihak demi percepatan pembangunan berkelanjutan atau yang disebut dengan PPP (public private partnership). Public privat partnership bisa dilakukan antara pemerintah, organisasi bisnis atau nirlaba atau organisasi lainnya. Seperti yang diungkapkan oleh Nugroho (2011:180):

PPP is a form of privatization, since in its basic principle the strategic government's accountability toward public services is being transferred to parties other than the government. These can be business corporations or non-profit organizations or other organizations. The transfer is done by contracting out, concession, or divestment.
Terdapat beberapa unsur dalam kemitraan, yaitu : pertama, adanya kesepatakan antar pihak. Kedua, adanya kerjasama. Ketiga, adanya kewajiban antarpihak. Keempat, menanggung resiko atau keuntungan. Kelima, mengevaluasi hubungan kerjasama (Rahmatullah, 2017:110). Berbagai usaha yang dilakukan dalam mengembangan Desa Wisata Sukaratu salah satu tujuannya adalah agar kegiatan yang dilakukan dapat berjalan dengan efektif dan efisien seperti yang diungkapkan oleh Setiawan (2012:185), PPPs provide benefits in the form of efficiency and effectiveness in the provision of quality public services.

Secara rinci, terdapat tiga dimensi alasan dibutukannya PPP (Public Private Partnership) menurut Fafurida (2017:4) sebagai berikut :

First is the political reason for creating a democratic government and encouraging the good governance and the good society. Second is the administrative reason due to the limitations of the government resources, both in terms of budget, human resources, assets, and management capabilities. Third is the economic reason, which is reducing the disparity or inequality, spurring the growth and productivity, improving the quality and continuity, and reducing the risk.

Oleh karena itu, pentingnya intervensi pihak lain selain pemerintah untuk dilakukannya pemberdayaan dan pendampingan pengembangan Desa Wisata Sukaratu. Tim pengabdian yang berasal dari organisasi privat yaitu Universitas Serang Raya berkolaborasi dengan pemerintah terkait yaitu pihak Kementrian Parisiwisata Republik Indonesia dan Dinas Pariwisata Provinsi Banten serta Dinas Pariwisata Kabupaten Serang. Terdapat tiga skenario kemitraan yang dilakukan antara pihak Universitas Serang Raya dan pemerintah yaitu pola kemitraan kontraproduktif, pola kemitraan semiproduktif, dan pola kemitraan produktif (Rahmatullah, 2017:112). Pertama, pola kemitraan kontraproduktif. Masih berpijak pada pola konvensional yang hanya mengutamakan kepentingan shareholders yaitu mengejar profit sebesar-besarnya. Kedua, pola kemitraan Lingkungan Hidup dan Bencana 582 
semiproduktif. Pemerintah dan komunitas atau masyarakat dianggap sebagai objek dan masalah di luar perusahaan. Perusahaan tidak tahu programprogram pemerintah dan pemerintah juga tidak memberikan iklim yang kondusif kepada dunia usaha dan masyarakat bersifat pasif. Ketiga, pola kemitraan produktif. Pola ini yang cocok pada kegiatan ini karena menempatkan mitra sebagai subjek dan dalam paradigma commont interest dan prinsip simbiosis mutualisme sangat kental. Pihak kampus memiliki kepedulian sosial dan lingkungan yang tinggi dan didukung oleh pemerintah memberikan iklim yang kondusif. Mitra bisa dilibatkan pada pola hubungan resourced based partnership (mitra diberi kesempatan menjadi bagian dari stakeholders).

Mitra dalam kegiatan pengabdian ini adalah aparat Desa Sukaratu beserta perangkatnya, BUMDes Sukaratu, GAPOKTAN (GAbungan kelomPOK TANi), PPK (Paguyuban Putra Kadupugur), Kelompok Sadar Wisata, dan masyarakat Desa Sukaratu yang ikut terlibat dalam kegiatan ini. Tujuan khusus yang yang ingin dicapai adalah memberikan penyuluhan, pendampingan, memotivasi dan mengarahkan kepada mitra agar dapat mengembangkan Desa Wisata Sukaratu untuk dapat berdaya dan mandiri dan mampu mengeksplor potensi desa yang ada secara optimal sehingga manfaatnya untuk kesejahteraan masyarakat desa itu sendiri dengan adil dan berkesinambungan serta menghasilkan masyarakat yang mandiri serta terciptanya potensi masyarakat dalam mengeksplor sumber daya yang ada di desa tersebut. Menurut Kementrian Pariwisata (2019:14), Terdapat kriteria pengembangan desa wisata yang disebut dengan 4A+1C yaitu Attraction (atraksi wisata unggulan), amenities (fasilitas pendukung), accessibility (sarana-prasarana yang memadai), ancillaries (layanan tambahan termasuk kelembagaan/, dan community involvement (keterlibatan masyarakat). Pada kegiatan pemberdayaan dan pendampingan pengembangan Desa Wisata Sukaratu untuk saat ini fokus pada usaha melibatkan masyarakat agar potensi yang ada dapat dioptimalkan dengan baik.

\section{METODE}

Metode yang digunakan pada kegiatan ini adalah participatory learning and action yang merupakan metode pemberdayaan masyakat yang terdiri dari proses belajar melalui ceramah, curah pendapat, diskusi dan lain-lain tentang suatu topik. Melalui PLA orang luar dapat memainkan peran penghubung antara masyarakat setempat dengan lembaga lain yang diperlukan (Silmi, 2017:91). Kegiatan ini dilakukan dengan memberikan fokus dan perhatian pada kegiatan ceramah, diskusi, praktek dan simulasi, pelatihan skill sampai pada pembentukan komunitas yang dilakukan secara bersama-sama dan ada pula secara bertahap. Secara umum tahapan kegiatan pengabdian ini dapat dilihat

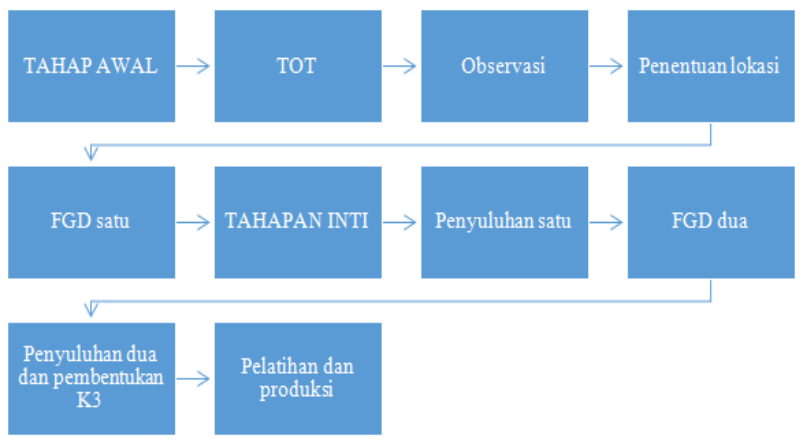

pada gambar 2 .

Gambar 2: Tahapan Kegiatan

Sumber: Tim Pengabdian, 2019

Berikut penjelasan pada masing-masing tahapan kegiatan : pertama, tahapan awal. Pada tahapan ini terdiri dari (a) tahapan kegiatan TOT (Training of Trainer. Tim pengabdian diberi pembekalan mengenai Desa Wisata oleh tim trainer dari Kementrian Pariwisata Republik Indonesia; (b) observasi, dilakukannya analisis awal untuk mendapatkan informasi dan data ke lokasi (desa) sehingga kedepannya akan lebih mudah untuk ditemukan soluasi yang dapat menyelesakan permasalahan yang ada; (c) penentuan lokasi yang akan dijadikan tempat dilaksanakannya kegiatan pengabdian dan pendampingan pengembangan desa wisata; (d) Forum Group Discussion tahap satu antar stakeholder untuk mengkaji desa wisata di Provinsi Banten secara komrehensif. Kedua, tahapan inti. Pada tahapan ini terdiri dari (a) penyuluhan dengan memaparkan materi terkait sadar wisata dan sapta pesona; (b) forum group discussion tahap dua mengenai optimalisasi potensi alam persawahan dan perkebunan yang ada di Desa Sukaratu dengan keterlibatan masyarakat; (c)

$$
\text { Lingkungan Hidup dan Bencana }
$$


penyuluhan kedua dan pembentukan komunitas di lingkungan Desa. Penyuluhan tahap ini lebih fokus pada pemanfaatan hasil alam dan limbah agar dapat dieksplor lebih baik lagi oleh warga setempat menjadi prodak baru dan pembentukan K3 (Kelompok Kreatif Kadupugur) yang akan konsen pada kegiatan keterampilan dan kreativitas hasil alam dan limbah; (d) pelatihan dan produksi pembuatan lampu hias berbahan dasar bambu, pembuatan papan jalan berbahan dasar limbah papan, pembuatan kursi yang berbahan dasar limbah botol plastik air mineral dan sisa kain perca dari limbah konveksi usaha warga setempat. Berikut terdapat luaran kegiatan pendampingan pada

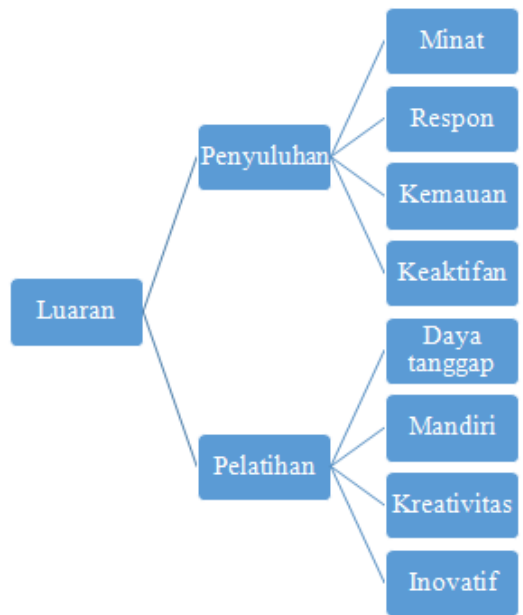

gambar 3.

Gambar 3 : Luaran Perkegiatan Pendampingan

Sumber : Tim Pengabdian, 2019

Alat evaluasi yang dipakai berupa angket dan tulisan dengan skoring penilaian rata-rata dengan presentase $>80 \%$ (excellent), 70-79\% (very good), 60-69\% (Acceptable), dan $<50 \%$ (not Acceptable).

\section{HASIL DAN PEMBAHASAN}

Kegiatan ini dilakukan selama kurang lebih enam bulan terhitung dari bulan Maret-Agustus 2019.

\section{Tahap Awal}

Pada tahap awal ini, tim dosen pendamping diberi pembekalan pada kegiatan TOT (Training of Trainer) yang diselenggarakan oleh pihak Kementrian Pariwisata Republik Indonesia dan Dinas Pariwisata Provinsi Banten. Kegiatan ini berlangsung selama 3 hari yaitu pada tanggal 18-20 Maret 2019 di Hotel Le Dian Serang. Materi yang disampaikan diantaranya latar belakang disleenggarakannya kegiatan ini yaitu karena untuk mengembangan desa wisata yang baik unggul, tidak dapat dilakukan oleh pemerintah. Oleh karena itu, butuh adanya kerjasama dan berkolaborasi dengan pihak lain dalam hal ini adalah perguruan tinggi baik negeri ataupun swasta karena memiliki fokus yang sama yaitu peduli terhadap sosial dan lingkungan serta dalam perguruan tinggi terdapat tri dharma perguruan tinggi salah satunya adalah pengebdian kepada masyarakat dan hal ini cocok dengan program ini. selain itu kegiatan ini dilakukan agar lebih efektif karena menjangkau pada perguruan tinggi yang dekat dengan lokasi (desa) yang akan dilakukan kegiatan serta efisen karena ada pembagian waktu dan tenaga. Selain itu materi yang disampikan pada kegiatan TOT ini adalah pengembangan desa wisata melalui pendampingan dalm rangka fasilitasi pelatihan masyarakat desa wisata, yang didalamnya terdapat materi konsep pengembangan desa wisata, konsep pembangunan desa wisata, wisata edukasi di desa wisata, konsep pendampingan, andragogi, komunikasi dan teknik prosentasi, supervisi, training and coaching, teknik monitoring dan evaluasi. Selain itu dibekali juga peran pendamping yang baik yaitu sebagai fasilitator, motivator, katalisator, negosiator, supervisor, komunikator, evaluator, dan edukator. Selain itu, secara khsuus disampaikan juga mengenai desa wisata yang ada di Provinsi Banten beserta statusnya yang disampikan oleh pihak Dinas Pariwisata Provinsi Banten. Pada proses kegiatan ini pada hari terakhir penentuan alternatif desa wisata mana yang akan dilakukan pendampingan. Oleh karena itu setelah kegiatan TOT ini selesai dilakukan observasi ke lokasi dimana tim dosen Universitas Serang Raya memiliki Desa Sukaratu karena desa itu sudah termasuk desa wisata dan sebelumnya merupakan desa binaan Universitas Serang Raya dan kedepan dilanjutkan lebih fokus kepada pengembangan desa wisata.

$$
\text { Lingkungan Hidup dan Bencana }
$$




\section{Kegiatan observasi dilakukan untuk} mengidentifikasi potensi dan permasalahan yang ada yang diimbangi dengan cross cek untuk mengetahui akurasi data melalui wawancara. Hasil observasi, survey, dan wawancara kemudian diolah dengan menggunakan matriks pada tabel 1.

Tabel 1 : Hasil Observasi, Survey, Wawancara, dan Analisis Situasi Sosial

\begin{tabular}{|c|c|c|}
\hline No & Aspek & Hasil Analisis \\
\hline 1 & Desa wisata & $\begin{array}{l}\text { Desa Sukaratu sudah } \\
\text { memiliki desa wisata } \\
\text { secara legal pada } \\
\text { tahun 2018 dengan } \\
\text { destinasi wisata } \\
\text { Mahkota Ratu dan } \\
\text { pada pertengahan } \\
\text { tahun ini telah dibuka } \\
\text { lagi destinasi baru } \\
\text { yang dinamakan } \\
\text { Taman Pesona. } \\
\text { Berdasar hasil } \\
\text { penilaian yang terdiri } \\
\text { dari delapan kriteria } \\
\text { yaitu kepemilikan dan } \\
\text { kepengurusan oleh } \\
\text { masyarakat, tratap } \\
\text { kontribusi terhadap } \\
\text { kesejahteraan sosial, } \\
\text { mendorong terjadinya } \\
\text { partisipasi interaktif } \\
\text { antara masyakarat } \\
\text { lokal dan pengunjung, } \\
\text { kualitas makanan dan } \\
\text { minuman, kualitas } \\
\text { akomodasi } \\
\text { (homestay), kinerja } \\
\text { friendly tour operator } \\
\text { maka Desa Wisata } \\
\text { Sukaratu masuk pada } \\
\text { status B, artinya desa } \\
\text { wisata berkembang, } \\
\text { belum menjadi desa } \\
\text { wisata maju atau } \\
\text { lebih tinggi lagi yaitu } \\
\text { mandiri sehingga } \\
\text { perlu adanya } \\
\text { intervensi dari } \\
\text { berbagai pihak. }\end{array}$ \\
\hline
\end{tabular}

2 Kesadaran wisata

Masyarakat setempat pada umumnya belum paham ada itu desa wiata karena memang baru setahun desa wisata sukaratu diresmikan sehingga belum tau bagaimana apa saja indikator desa tersebut menjadi desa wisata oleh karena itu banyak potensi desa yang belum tereksplor dengan baik

3 Sumber Daya Alam

Terdapat potensi alam berupa lahan pesawahan padi yang melimpah dan pekebunan tanaman rambutan, tanaman durian dn tanaman bambu namun potensi ini belum dioptimalkan terutama pada hasil perkebunan.

4 Papan petunjuk jalan Masih kurangnya papan petunjuk jalan untuk lokasi kawasan desa wisata sehingga tidak sedikit pengunjung yang kebingungan arah jalan ke destinasi lokasi wisata

\begin{tabular}{llr}
\hline 5 Limbah & Terdapat & usaha \\
& konveksi & yang \\
& limbahnya & belum \\
& dimanfaatkan dengan \\
& baik dan & botol air \\
& mineral & yang \\
& berserakan & \\
\hline
\end{tabular}

Sumber : Tim Pengabdian, 2019

Setalah dipilihnya Desa Sukaratu untuk dilakukannya pemberdayaan dan pendampingan kemudian dilakukan Forum Group Discussion pada tanggal 30 Maret 2019 yang diselenggarakan oleh 
Dinas Pariwisata Provinsi Banten mengenai "percepatan pengembangan destinasi pariwisata Provinsi Banten." Kegiatan yang dihadiri oleh pejabat Sekretaris Daerah Provinsi, Dinas Priwisata Kabuten dan Kota, para dosen tim pendamping desa wisata Provinsi Banten serta mitra kerja Dinas Pariwisata.Kegiatan disini mengajak kepada semua pihak bahwa untuk dapat mengembangakan pariwisata khususnya di Desa harus berkolaborasi karena semuanya berkaitan dengan bersama-sama memajukan Banten.

\section{Tahap Inti}

Pada tahap ini akan dilakukan beberapa tahapan yaitu dapat dilihat pada tabel 2 .

Tabel 2 : Jadwal Kegiatan Inti

\begin{tabular}{|l|l|l|l|}
\hline No & Kegiatan & Jadwal & Ket. \\
\hline 1 & $\begin{array}{l}\text { Penyuluhan tahap } \\
\text { satu ini mengenai } \\
\text { sadar wisata dan } \\
\text { pemamparan } \\
\text { mengenai sapta } \\
\text { pesona. }\end{array}$ & Tim \\
\hline 2 & $\begin{array}{l}\text { Forum Group } \\
\text { Discussion tahap dua } \\
\text { yang lebih fokus } \\
\text { dibahas dengan } \\
\text { aparat desa setempat } \\
\text { beserta warga } \\
\text { masyarakat } \\
\text { mengenai } \\
\text { pengoptimalan } \\
\text { potensidesa }\end{array}$ & Tim \\
\hline 3 & $\begin{array}{l}\text { Penyuluhan kedua } \\
\text { sekaligus } \\
\text { pembetukan K3 } \\
\text { (Kelompok Kreatif } \\
\text { Kadupugur) }\end{array}$ & 15 & Agustus \\
\hline 4 & $\begin{array}{l}\text { Pelatihan pembuatan } \\
\text { bamboo lamp, kursi } \\
\text { dan papan jalan dan } \\
\text { produksi }\end{array}$ & $\begin{array}{l}\text { Tim } \\
\text { Agustus } \\
2019\end{array}$ & Tim dan \\
warga
\end{tabular}

Sumber : Tim Pengabdian, 2019

$\underline{\text { Penyuluhan Tahap Satu }}$

Kegiatan ini dilaksanakan pada pada tanggal 29 juni 2019 di ruang petemuan
GAPOKTAN di Desa Sukaratu yang berlokasi di kawasan Desa Wisata Sukaratu. Kegiatan ini dihadiri oleh pihak Kementrian Pariwisata Republik Indonesia, Dinas pariwisata Kabupaten Serang, kepala Desa dan perangkatnya, pengelola BUMDes Desa Sukaratu, anggota GAPOKTAN, dan warga Desa Sukaratu pada umumnya. Materi yang sampaikan mngenai sadar wisata dan sapta pesona. Hal ini disampaikan karena urgensi dari pengembangan desa wisata harus terlebih dahulu diberi kesadaran kepada warga sehingga tahu dan paham dan mudah mengikuti kegiatan proses pengembangan desa wisata. keterlibatan masyarakat penting untuk bersama-sama membangun desa. selain itu disampaikan materi mengenai sapta pesona. Sapta pesona harus diwujudkan dalam rangka menarik minat pengunjung yang terdiri dari tujuh unsur yaitu aman, tertib, bersih, sejuk, indah, ramah tamah, dan kenangan. Berikut tampilan kegiatan penyululuhan tahap satu dapat dilihat pada gambar 4.

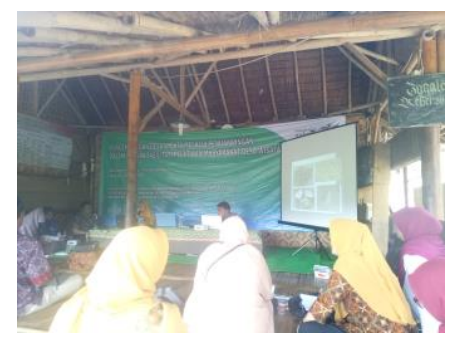

Gambar 4. Kegiatan penyuluhan tahap satu Sumber: Tim Pengabdian, 2019

\section{Forum Group Discussion tahap dua}

Pada tahap ini dilakukan kembali kegiatan FGD pada tanggal 7 Agustus 2019 secara lebih fokus membahas mengenai ekplorasi potensi desa yaitu hasil dari perkebunan, pemanfaatan limbah dan pemahaman pembuatan jalur wisata yang baik. Hasil ini didapat bahwa di Desa Sukaratu memiliki potensi perkebunan bambu, buah rambutan dan buah durian serta terdapat limbah konveksi (kain). Namun pada kesempatan kegiatan ini kali ini, tanaman rambutan dan durian sedang tidak musim namun untuk tanaman bambu tidak mengenal musim sehingga akan selalu tumbuh. Hal ini tidak diiringi dengan optimaliasi bambu sehingga Lingkungan Hidup dan Bencana $\quad 586$ 
penjualan yang dilakukan dalam bentuk bambu yang dihargai hanya seribu rupiah. Oleh karena itu, kedepan akan dieksplor menjadi lampu hias berbahan dasar bambu. Selain itu terdapat limbah air botol mineral dan limbah produksi konveksi berupa kain dan hal ini akan dibuat kursi. Sebagai tambahan akan dibuatkan papan jalan untuk mempermudah pengujung jika ke kawasan Desa Wisata Sukaratu. Kedepan akan dibentuk komunitas yang fokus mengeksplor potensi yang ada agar lebih mudah di monitoring dan dilihat kemajuannya.

Penyuluhan kedua dan Pembentukan K3

Pada tahap ini dilakukan kembali
penyuluhan tetapi penyuluhan ini lebih fokus mengenai pembuatan lampu bambu, kursi, dan papan jalan. Selain itu diperlihatkan kepada warga contoh design lampu hias bambu, kursi, dan papan jalan. Paa kegiatan ini diberikan pula materi mengenai UMKM sebagai penggerak perekonomian Desa sehingga diharapkan stimulasi ini "menggurita" bagi warga terlibat dalam membuka usaha yang memanfaatkan potensi desa dengan baik. Disamping itu disampaikan pula mengenai strategi marketing masa kini agar hasil usaha dapat dijangkau tidak hanya di dalam desa namun bisa lintas daerah. Pada akhir kegiatan peresmian dibentuknya Kelompok Kreatif kadupugur (K3). Kadupugur merupakan salah satu nama perkampungan di Desa Sukaratu yang menjadi penyanggah destinasi baru di Taman Pesona. Berikut kegiatan penyuluhan tahap dua dan peresmian pembentukan K3 (Kelompok Kreatif Kadupugur) yang diakhir dengan penyerahan sampel lampu hias bambu dan kursi berbahan dasar limbah serta papan jalan dapat dilihat pada gambar 5.

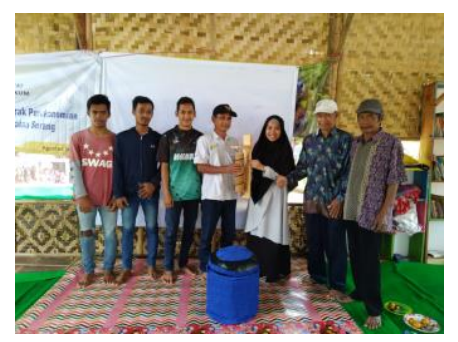

Gambar 5. Penyuluhan tahap kedua dan peresmian Kelompok Kreatif Kadupugur

Sumber : Tim Pengabdian, 2019

\section{Pelatihan dan Produksi}

Pada tahap ini, warga yang tergabung pada K3 (Kelompok Kreatif Kadupugur) diberikan pelatihan pembuatan lampu hias berbagan dasar bambu, pembuatan kursi, dan papan jalan. Proses pelatihan pembuatan kursi berbahan dasar limbah dapat dilihat pada gambar 6 di bawah ini.

Gambar 6: proses pembuatan kursi berbagan dasar

limbah

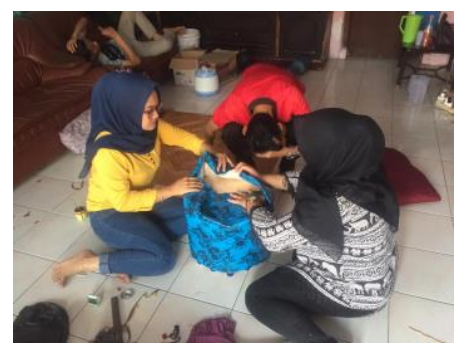

Sumber : Tim Pengabdian, 2019

Kegiatan yang berlangsung selama dua hari ini yaitu tanggal 18-19 Agustus 2019 tidah hanya diikuti oleh K3 namun dapat diikuti oleh warga pada umumnya agar tahu dan termotivasi untuk membuat kerajinan ini. Untuk proses pembuatan papan jalan dapat dilihat pada gambar 7 sebagai berikut.

Gambar 7 : proses pembuatan papan jalan

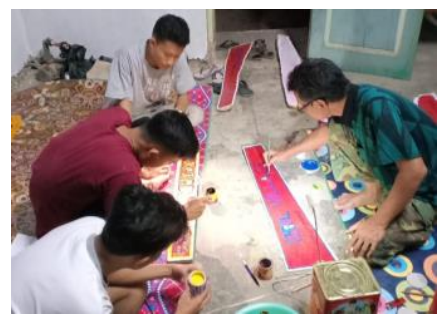

Sumber : Tim Pengabdian, 2019

Pada proses ini sudah ada pesanan lampu dan kursi baik dari warga setempat maupun lintas daerah. Setelah dilakukan pelatihan dan pembetukan K3 diharapkan kelompok ini dapat eksis dan memproduksi barang dengan cukup baik. 
Berikut tampilan lampu hias yang telah dibuat dapat dilihat pada gambar 8 .

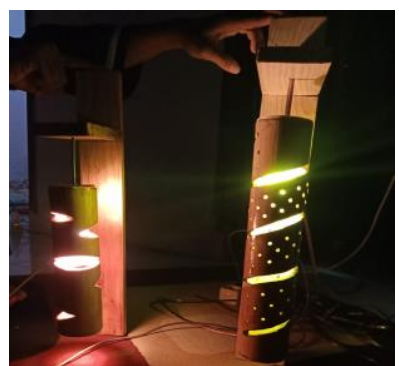

Gambar 8 : Tampilan lampu hias bambu

Sumber : Tim Pengabdian, 2019

Tingkat pencapaian dari kegiatan ini yaitu Aparat desa dan perangkat desa, BUMDes, POKDARWIS, masyarakat pada umumnya berminat untuk berpartisipasi mengembangkan desa wisata, memiliki kemauan untuk terus menggali potensi yang ada sehingga desa sukaratu menjadi berkembang lebih baik, akan ikut aktif dalam kegiatan yang diadakan di desa sukaratu terkait proses pengembangan desa wisatanya. Berikut hasil angket atau pertanyaan mengenai minat, respon, kemamuan, dan keaktifan pada kegiatan penyuluhan pertama dipaparkan pada tabel 3 .

\begin{tabular}{|c|c|}
\hline Instrumen pertanyaan & Hasil \\
\hline Minat & $\begin{array}{l}13 \text { warga menjawab } \\
\text { sangat berminat, } 19 \\
\text { warga menjawab } \\
\text { berminat, } 2 \text { menjawab } \\
\text { tidak berminat dan tidak } \\
\text { ada yang menjawab } \\
\text { sangat tidak berminat }\end{array}$ \\
\hline Respon & $\begin{array}{l}12 \text { menjawab sangat } \\
\text { merespon, } 19 \text { menjawab } \\
\text { merespon, } 2 \text { menjawab } \\
\text { tidak merespon, dan } \\
\text { tidak ada yng menjawab } \\
\text { sangat tidak merespon }\end{array}$ \\
\hline Kemauan & $\begin{array}{l}11 \text { menjawab sangat ada } \\
\text { kemauan, } 20 \text { menjawab } \\
\text { mau, } 3 \text { menjawab tidak } \\
\text { mau, dan tidak ada yang } \\
\text { menjawab sangat tidak } \\
\text { ada kemauan }\end{array}$ \\
\hline
\end{tabular}

\begin{tabular}{|l|l|}
\hline Keaktifan & 7 menjawab sangat \\
& aktif, 20 menjawab \\
aktif, 7 menjawab tidak \\
aktif, dan tidak ada yang \\
menjawab sangat tidak \\
aktif.
\end{tabular}

Sumber : Tim Pengabdian, 2019

Berdasar hasil paparan di atas dijelaskan bahwa untuk instrumen pertanyaan minat hampir sebagaian besar yaitu 19 warga dengan range 70$79 \%$ berminat mengembangan desa wisata. untuk instrumen respon sebanyak 19 warga dengan range $70-79 \%$ merepon dengan baik. Instrumen kemauan sebanyak 20 warga dengan range 70$79 \%$ artinya ada kemauan warga untuk berpartisipasi mengembangan desa wisata. instrumen terakhir yaitu keaktifan sebanyak 20 dengan range $70-79 \%$ mayoritas menjawab ingin aktif terlibat.

Berikut hasil angket atau pertanyaan mengenai minat, respon, kemamuan, dan keaktifan pada kegiatan penyuluhan kedua mengenai eksplorasi potensi desa sukaratu dengan pemanfaatan bahan dasar yang tersedia yaitu tanaman bambu, limbah botol air mineral dan kain limbah konveksi serta pembuatan papan jalan dipaparkan pada tabel 4.

\begin{tabular}{|l|l|}
\hline Instrumen pertanyaan & Hasil \\
\hline Minat & $\begin{array}{l}\text { warga menjawab } \\
\text { sangat berminat, 6 } \\
\text { warga } \quad \text { menjawab } \\
\text { berminat, 7 menjawab } \\
\text { tidak berminat dan tidak } \\
\text { ada yang menjawab } \\
\text { sangat tidak berminat }\end{array}$ \\
\hline Respon & $\begin{array}{l}\text { merespon, 10 menjawab } \\
\text { merespon, 6 menjawab } \\
\text { tidak merespon, dan } \\
\text { tidak ada yng menjawab } \\
\text { sangat tidak merespon }\end{array}$ \\
\hline Kemauan & 5 menjawab sangat ada \\
\hline
\end{tabular}




\begin{tabular}{|l|l|}
\hline & $\begin{array}{l}\text { kemauan, 15 menjawab } \\
\text { mau, 8 menjawab tidak } \\
\text { mau, dan tidak ada yang } \\
\text { menjawab sangat tidak } \\
\text { ada kemauan }\end{array}$ \\
\hline Keaktifan & $\begin{array}{l}\text { aktif, 10 menjawab sangat } \\
\text { aktif, 9 menjawab tidak } \\
\text { aktif, dan tidak ada yang } \\
\text { menjawab sangat tidak } \\
\text { aktif }\end{array}$ \\
\hline
\end{tabular}

Sumber : Tim pengabdian, 2019

Berdasar hasil paparan di atas dijelaskan bahwa untuk instrumen pertanyaan sangat berminat dalam pembuatan kreatifitas bambu dan kursi berbagan dasar limbah serta papan jalan sebanyak 15 warga dengan range $>80 \%$. Instrumen respon mayoritas menjawab sangat mersepon yaitu sebanyak 12 dengan range $>80 \%$. Instrumen kemauan sebanyak mayoritas menjawab mau berpartisipasi membuat lampu bambu, kursi, dan papan jalan sebanyak 15 warga dengan range 70-79\%. Instrumen terakhir yaitu keaktifan mayoritas akan aktif terlibat sebanyak 10 dengan range $70-79 \%$.

Berikut hasil angket atau pertanyaan mengenai daya tanggap, mandiri, kreatifitas, inovatif pada kegiatan pelatihan pembuatan lambu hias berbahan dasar gambu, pembuatan kursi berbahan dasar limbah dan pembuatan papan jalan dipaparkan pada tabel 5.

\begin{tabular}{|l|l|}
\hline Instrumen pertanyaan & Hasil \\
\hline Daya tanggap & 3 menjawab sangat \\
& $\begin{array}{l}\text { tanggap, 6 menjawab } \\
\text { tanggap, 1 menjawab } \\
\text { tidak tanggap, dan tidak } \\
\text { ada yang menjawab } \\
\text { sangat tidak tanggap }\end{array}$ \\
\hline Mandiri & $\begin{array}{l}\text { menjawab sangat } \\
\text { mandiri, 5 menjawab } \\
\text { mandiri, 3 menjawab } \\
\text { tidak mandiri, dan tidak } \\
\text { ada yang menjawab } \\
\text { sangat tidak mandiri }\end{array}$ \\
\hline
\end{tabular}

\begin{tabular}{|l|l|}
\hline Kreativitas & 3 menjawab sangat \\
kreatif, 5 menjawab \\
kreatif, 2 menjawab \\
tidak kreatif, dan tidak \\
ada yang menjawab \\
sangat tidak kreatif
\end{tabular}

Sumber: Tim pengabidan, 2019

Berdasar hasil paparan di atas dijelaskan bahwa untuk instrumen pertanyaan daya tanggap mayoritas mejawab tanggap yaitu sebanyak 6 dengan range $70-79 \%$. Instrumen mandiri mayoritas menjawab mandiri yaitu sebanyak 5 warga dengan range $70-79 \%$. Instrumen kreativitas mayoritas menjawab kreatif sebanyak 5 warga dengan range 70-79\%. Instrumen inovatif mayoritas menjawab tidak inovatif sebanyak 8 warga dengan range 60$69 \%$.

Berbagai kegiatan pengabdian yang telah dilakukan ini, kedepan masih harus terus dilakukan khususnya dalam hal monitoring dan evaluasi keberadaan K3 (Kelompok Kreatif Kadupugur) yang telah terbentuk serta proses kegiatannya dalam membuat kerajinan kursi dan lampu bambu hias.

\section{KESIMPULAN}

Berdasar kegiatan yang telah dilaksanakan maka dapat disimpulkan bahwa warga pada umumnya mengikuti kegiatan ini dengan baik walaupun masih perlu adanya pendampingan lebih lanjut agar kegiatan yang sebelumnya dapat terlihat perkembangannya dari hasil kegiatan pemberdayaan dan pendampingan yang selama ini telah diberikan. Tingkat pencapaian keberhasilan selama kegiatan ini berada pada kategori $75 \%$ dengan skala sangat baik pada kegiatan penyuluhan yang pertama. Sedangkan untuk kegiatan penyuluhan yang kedua didapat skala yang sama yaitu sangat baik dengan presentase $73 \%$. Terakhir untuk pencapaian kegiatan pelatihan pembuatan lampu berbagan dasar

$$
\text { Lingkungan Hidup dan Bencana }
$$


bambu, kursi dari limbah produksi konveksi dan botol air mineral serta pembuatan papan jalan masuk pada skala yang sama yaitu sangat baik dengan presentase $70 \%$.

Rekomendasi dalam kegiatan ini adalah perlu ditambahkan mitra baik dari pihak pemerintah atau swasta dan terjalin kerjasama yang kuat dalam mengembangan desa wisata sukaratu sehingga outcome yang diterima kembali lagi untuk kesejahteraan masyarakat khususnya masyarakat lokal Desa Sukaratu. Seperti pembangunan infrastruktur jalan, menyiapkan fasilitas publik berupa transportasi lokal oleh warga setempat, menambahkan destinasi baru serta perlu adanya eksplorasi potensi sumber daya yang ada secara berkesinambungan.

\section{REFERENSI}

Asisten Deputi Pengembangan SDM Pariwisata dan Hubungan Antarlembaga Kementerian Pariwisata Republik Indonesia. 2019. Buku Panduan Pengembangan Desa Wisata Berbasis Pendampingan melalui Perguruan Tinggi.

Budiman, Arif. 1996. Teori Pembangunan Dunia Ketiga. Jakarta: PT Gramedia Pustaka Utama.

Fafurida; Ni'mah,Izzatun. 2017. Public-Private Partnership to Increase Economic Growth of Tourism Sector. Jurnal Ekonomi Pembangunan, 18 (1), 2017, 1-18

Nugroho, Rian. 2011. Public Private Partnership as a Policy Dillema. International Journal of Administrative Science \& Organization Bisnis \& Birokrasi,
Jurnal Ilmu Administrasi dan Organisasi Volume 18 Number 3.

Rahmatullah. 2017. Buku Pintar Corporate Social Responsibility. Yogyakarta: Saamudra Biru (Anggota IKAPI).

Rosidin, utang. 2019. Pemberdayaan Desa dalam Sistem Pemerintahan Desa Perspektif Undang-Undang Nomor 6 Tahun 2014). Bandung : CV Pustaka Setia

Setiawan, Tomi., Sukma F, Egnas. 2012. Public Private Partnership as a Public Service Dillema. International Journal of Administrative Science \& Organization Bisnis \& Birokrasi, Jurnal Ilmu Administrasi dan Organisasi Volume 19 Number 3.

Silmi, A Fatharani. 2017. Participatory Learning and Action (PLA) di Desa Terpencil (Peran LSM Provinsi Yogyakarta dalam Pemberdayaan Masyarakat di Lubuk Bintialo Sumatra Selatan. Jurnal Pemberdayaan Masyarakat: Media Pemikiran dan Dakwah Pembangunan Volume 1 Nomor 1 hal 81-98

Susanti, Martien H. 2017. Peran Pendamping Desa Dalam Mendorong Prakarsa Dan Partisipasi Masyarakat Menuju Desa Mandiri Di Desa Gonoharjo Kecamatan Limbangan Kabupaten Kendal. Jurnal Integralistik No.1/Th. XXVIII/2017, Januari-Juni 2017

Triyono, Agus. 2014. Pemberdayaan Masyarakat Melalui Community Development Program Posdaya (Pos Pemberdayaan Keluarga) Pt. Holcim Indonesia Tbk Pabrik Cilacap. Jurnal Komuniti Vol 6 No.2 